\title{
Implementasi Pompa Air pada Tambak Udang dengan Pemanfaatan Sumber Energi Terbarukan
}

\author{
Jalaluddin $^{1 *}$, Abdul Rasyid Jalil ${ }^{2}$, Rustan Tarakka ${ }^{1}$, Wardi $^{3}$ \\ Departemen Teknik Mesin ${ }^{1}$, Departemen Teknik Elektro ${ }^{3}$ Fakultas Teknik UNHAS \\ Departemen Ilmu Kelautan ${ }^{2}$ Fakultas Ilmu Kelautan dan Perikanan UNHAS \\ jalaluddin_had@yahoo.com ${ }^{1 *}$
}

\begin{abstract}
Abstrak
Sosialisasi dan implementasi pemanfaatan sumber energi terbarukan kepada masyarakat terus-menerus digalakkan. Pemanfaatan sumber energi terbarukan dengan penerapan teknologi sel photovoltaik (PV) untuk suplai energi secara terintegrasi dilakukan untuk membantu penyediaan energi yang diperlukan pada areal tambak di kabupaten Pinrang, Sulawesi Selatan. Energi tersebut digunakan untuk pengoperasian peralatan pendukung sperti pompa air dan penggunaan lainnya. Sosialisasi dan implementasi pemanfaatan sumber energi terbarukan dengan teknologi sel photovoltaik untuk menjalankan pompa air dan penggunaan lainnya pada tambak udang telah dilakukan. Pelatihan masyarakat terkait pembuatan, operasional dan perawatan peralatan tersebut juga telah dilakukan. Masyarakat kecamatan Lanrisang kabupaten Pinrang yang terdiri dari beberapa desa dan kelurahan diberi pengetahuan tentang pemanfaatan peralatan yang terkait dan dilatih untuk melakukan perakitan dan pengoperasian peralatan. Beberapa kelompok masyarakat tertentu yang berprofesi dalam bidang perbengkelan juga telah dilatih secara khusus untuk mendukung dalam perakitan dan perawatan peralatan. Masyarakat dan pemerintah setempat secara antusias telah berpartisipasi dalam kegiatan ini. Pengujian lapangan terhadap pompa air juga telah dilakukan sebagai panduan dalam aplikasi. Debit air rata-rata harian dari pompa air adalah sekitar $0.375 \mathrm{~L} / \mathrm{s}$. Sebagai contoh, tambak udang seluas 50 x 50 meter mempunyai kebutuhan suplai air sebesar $2.64 \mathrm{~m}^{3}$ maka pompa akan dijalankan selama 2 jam perhari.
\end{abstract}

Kata Kunci: Sumber Energi Terbarukan; Penerapan Sel Photovoltaik; Pompa Air; Sosialisasi dan Implementasi.

\section{Pendahuluan}

Komoditas udang mempunyai pangsa pasar yang luas dan relatif stabil di pasaran dunia sehingga usaha budidaya udang, yang umumnya dilakukan di tambak, merupakan kegiatan yang sangat menjanjikan. Beberapa daerah kabupaten di Sulawesi Selatan mempunyai potensi yang besar untuk usaha budidaya udang seperti Kabupaten Takalar, Maros, Pangkep, Barru, Pinrang, dll. Pada umumnya budidaya udang ini dilakukan secara tradisional. Beberapa tambak udang telah mengaplikasikan teknologi masih terkendala dengan pembiayaan yang sangat besar. Sumber energi listrik yang mereka gunakan umumnya bersumber dari PLN atau menggunakan generator listrik.

Kabupaten Pinrang merupakan salah satu daerah kabupaten yang memiliki potensi yang besar dalam budidaya udang secara goegrafis terletak di 43 10'30" - 30 19'30" lintang utara dan 119 26'30" - 11947 ' 20" bujur timur. Luas wilayahnya adalah $1.961 .77 \mathrm{~km}^{2}$ atau $3.15 \%$ dari luas Sulawesi Selatan dengan 12 kecamatan, 39 Kelurahan dan 65 Desa. Batas wilayahnya antara lain: kabupaten Tana Toraja di sebelah utara, Kota madya Pare-pare di sebelah selatan, Kabupaten Polman dan selat Makassar di sebelah barat dan kabupaten Enrekang dan Kabupaten Sidrap di sebelah timur. 
Kabupaten Pinrang memiliki sumber daya perikanan yang cukup besar dan merupakan salah satu sektor andalan bagi perekonomian daerah. Potensi pertambakan seluas 15.026,20 Ha atau 22,72\% dengan rincian perkecamatan sebagai berikut (Dinas Kelautan dan Perikanan, 2012):

Tabel 1. Potensi Pertambakan

\begin{tabular}{|c|c|c|c|c|c|}
\hline \multirow{2}{*}{ No } & \multirow{2}{*}{ KECAMATAN } & \multirow{2}{*}{$\begin{array}{c}\text { LUAS } \\
\text { TAMBAK } \\
\text { (Ha) }\end{array}$} & \multicolumn{2}{|c|}{ PRODUKSI UDANG } & \multirow{2}{*}{$\begin{array}{c}\text { JUMLAH } \\
\text { PETANI } \\
\text { TAMBAK } \\
\text { (Org) }\end{array}$} \\
\hline & & & 2010 & 2011 & \\
\hline 1 & SUPPA & $1.599,22$ & $1.370,10$ & $1.409,80$ & 1.640 \\
\hline 2 & LANRISANG & $1.670,63$ & 264,70 & 267,90 & 895 \\
\hline 3 & CEMPA & $2.215,27$ & 238,70 & 274,20 & 1.094 \\
\hline 4 & MATTIRO SOMPE & $3.804,34$ & 603,60 & 657,80 & 3.863 \\
\hline 5 & DUAMPANUA & $5.401,74$ & 753,50 & 800,80 & 3.840 \\
\hline 6 & LEMBANG & 339,00 & 82,50 & 76,90 & 278 \\
\hline & TOTAL & $15.026,20$ & $3.313,10$ & $3.487,40$ & 11.598 \\
\hline
\end{tabular}

Permasalahan yang dialami oleh petani budidaya tambak udang di kabupaten Pinrang adalah sebagai berikut (Mahmud et al, 2007): 1) Budidaya tambak udang masih dilakukan secara tradisional, 2) Proses produksi masih lemah.

Untuk menciptakan sistem budidaya tambak udang yang lebih baik perlu didukung upaya-upaya untuk menggunakan peralatan tambahan, seperti beberapa peralatan pendukung antara lain kincir aerator, pompa air dan penerangan. Peralatan ini membutuhkan sumber energi listrik. Konsep Mandiri Energi pada tambak udang telah dilakukan dengan pemanfaatan sumber energi terbarukan ramah lingkungan dengan penerapan teknologi sel photovoltaik (PV) sebagai sumber energi listrik. Aplikasi teknologi sel PV dalam penyediaan sumber energi listrik untuk menjalankan kincir aerator pada tambak udang dan untuk penerangan pada di areal tambak udang telah dilakukan (Jalaluddin dkk, 2015). Pemanfaatan sumber energi listrik untuk menjalankan pompa air dengan aplikasi teknologi sel PV seperti terlihat pada gambar 1 akan diuraikan secara detail dalam tulisan ini.

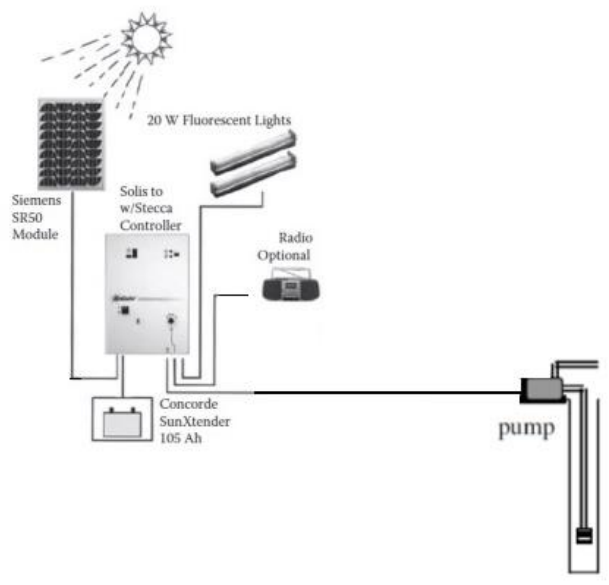

Gambar 1. Teknologi Sel PV untuk Pompa Air dan Penggunaan Lainnya

Teknologi sel PV telah banyak digunakan sebagai sumber energi untuk berbagai peralatan dan penerangan. Beberapa penelitian tentang sel PV dan aplikasinya telah dilakukan di Laboratorium 
Energi Terbarukan Departemen Teknik Mesin Universitas Hasanuddin (UNHAS). Penelitian tersebut antara lain: pemanfaatan sel PV untuk penggerak pompa tambak (Shiddiq dan Multazam, 2015), penggerak prototipe kincir aerator (Azhar dan Nasri, 2015) dan penggerak pompa rumahan (Arfandy dkk, 2016). Selain itu, analisis unjuk kerja sel PV dengan pengarah matahari (Jalaluddin dan Mire, 2015) dan dengan penggunaan air pendingin di bawah panel (Hasbi, 2014), (Jalaluddin dkk, 2016) telah dilakukan.

Kegiatan pengabdian masyarakat ini bertujuan untuk mengaplikasikan teknologi sel PV dalam penyediaan sumber energi listrik untuk menjalankan pompa air pada tambak udang dan untuk penggunaan lainnya seperti penerangan pada malam hari di areal tambak udang. Target yang telah didapatkan dari kegiatan ini adalah peningkatan pengetahuan dan keterampilan masyarakat/petani tambak dalam penerapan teknologi sel PV sebagai sumber energi untuk pengelolaan tambak. Selain itu, areal tambak percontohan skala kecil telah dibuat untuk membantu masyarakat dalam mengaplikasikan teknologi ini. Selanjutnya, rekomendasi aplikasi operasional pompa air tambak juga akan diuraikan.

\section{Metode}

Kegiatan pengabdian masyarakat ini dilaksanakan pada Juli-Agustus 2016 yang berlokasi di Kelurahan Lanrisang, Kecamatan Lanrisang, Kabupaten Pinrang, Sulawesi Selatan. Mahasiswa yang terlibat dalam kegiatan ini sebanyak 32 orang dengan 4 orang dosen pendamping lapangan. Program kerja utama adalah penerapan teknologi sel photovoltaik untuk suplai energi untuk menjalankan pompa air dan penerangan di areal tambak udang. Beberapa akivitas yang dilakukan terkait dengan program kerja utama antara lain: 1) Aktivitas bersama mehasiswa dan masyarakat untuk pemasangan sel photovoltaik beserta sistem penyimpanan energi dan pendistribusiannya dengan renovasi bangunan kecil di pinggir tambak; dan 2) Pelatihan petani tambak tentang pemasangan sel PV beserta sistem penyimpanan energi dan pendistribusiannya. Program kerja tambahan juga dilakukan untuk lebih bersosialisasi dengan masyarakat dan mengakomodasi keinginan masyarakat. Program Kerja utama dari kegiatan ini adalah 1) sosialisasi dan implementasi pemanfaatan energi terbarukan sebagai sumber energi untuk pompa air dan penggunaan lainnya dengan menggunakan sel PV, 2) pelatihan masyarakat terkait pembuatan, operasional dan perawatan sistem peralatan sel PV.

\section{Hasil dan Diskusi}

Sosialisasi dan implementasi pemanfaatan sumber energi terbarukan kepada masyarakat di Kabupaten Pinrang, Sulawesi Selatan telah dilaksanakan. Program ini dilaksanakan dengan pemanfaatan energi terbarukan menggunakan teknologi sel PV sebagai sumber energi untuk menjalankan pompa air dan penggunaan lainnya seperti penerangan pada malam hari di areal tambak udang. Kegiatan ini untuk melanjutkan program pemanfaatan sumber energi tebarukan untuk menjalankan kincir aerator tambak udang (Jalaluddin dkk, 2015) dalam konsep mandiri energi pada tambak udang. Pemanfaatan sel photovoltaik sebagai sumber energi untuk menjalankan pompa air dilakukan untuk mendukung program mandiri energi tersebut. Persiapan dilakukan dengan pembuatan dan pengujian prototipe peralatan. Prototipe peralatan dibuat dilakukan di laboratorium Energi Terbarukan Departemen Teknik Mesin UNHAS seperti terlihat pada gambar 2. Beberapa mahasiswa dan staf laboran dilibatkan dalam pembuatan prototipe ini. Peralatan ini terdiri dari: modul sel PV sebanyak 3 buah masing-masing berkapasitas 50 WP, motor DC 12 volt sebagai penggerak pompa air, baterai 50 Ah, lampu LED 5 Watt sebanyak 2 buah dan inverter DC $12 \mathrm{~V}-\mathrm{AC} 220 \mathrm{~V}$. 


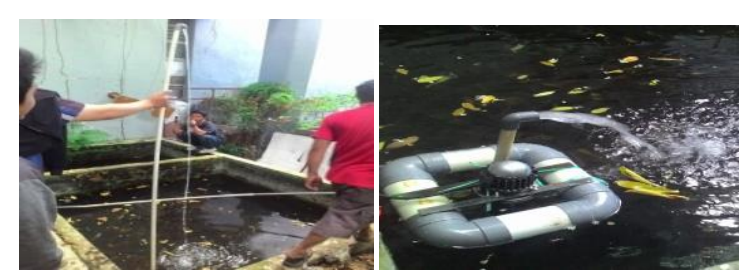

Gambar 2. Pengujian Prototipe Pompa air

Pelaksanaan program kerja diawali dengan penyusunan program kerja yang dihadiri masyarakat dan pemerintah setempat seperti terlihat pada Gambar 3. Beberapa program kerja tambahan juga dilakukan untuk lebih memudahkan dalam pendekatan dalam rangka pelaksanaan program kerja utama kepada masyarakat dan pemerintah setempat. Pemanfaatan teknologi sel PV sebagai sumber energi menjalankan pompa air dan penggunaan lainnya seperti penerangan dilakukan secara langsung di areal tambak masyarakat. Energi matahari yang disimpan pada baterai digunakan juga untuk penggunaan lainnya seperti sumber energi untuk radio, telepon genggam dan menyalakan lampu penerangan pada malam hari. Selanjutnya, pelatihan pembuatan, perakitan dan pengoperasian peralatan kepada beberapa kelompok masyarakat dilakukan secara bergantian sesuai dengan ketersedian waktu masing-masing kelompok untuk hadir di lokasi pemasangan peralatan tersebut. Sosialisasi kepada masyarakat dilakukan secara langsung untuk beberapa kelompok masyarakat di beberapa desa dan kelurahan secara terpisah. Instalasi peralatan dilakukan secara secara bersama-sama antara mahasiswa, dosen pendamping dan perwakilan beberapa kelompok masyarakat. Selanjutnya, pelatihan kepada masyarakat tentang pembuatan, perakitan dan pengoperasian dilakukan kepada beberapa kelompok masyarakat dari beberapa desa dan kelurahan secara bergantian di areal tambak percontohan tempat pemasangan peralatan tersebut. Aktifitas sosialisasi dan pelatihan ini dapat dilihat pada Gambar 4 dan 5 .

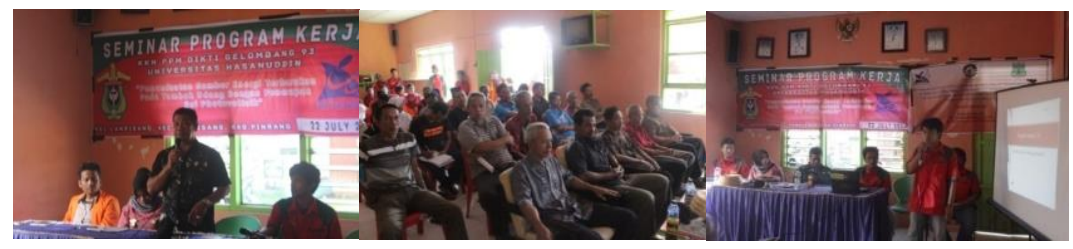

Gambar 3. Penyusunan Program Kerja Bersama Pemerintah dan Masyarakat

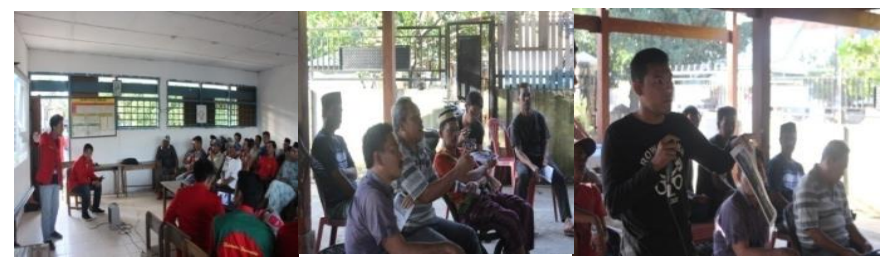

Gambar 4. Sosialisasi kepada Masyarakat. 


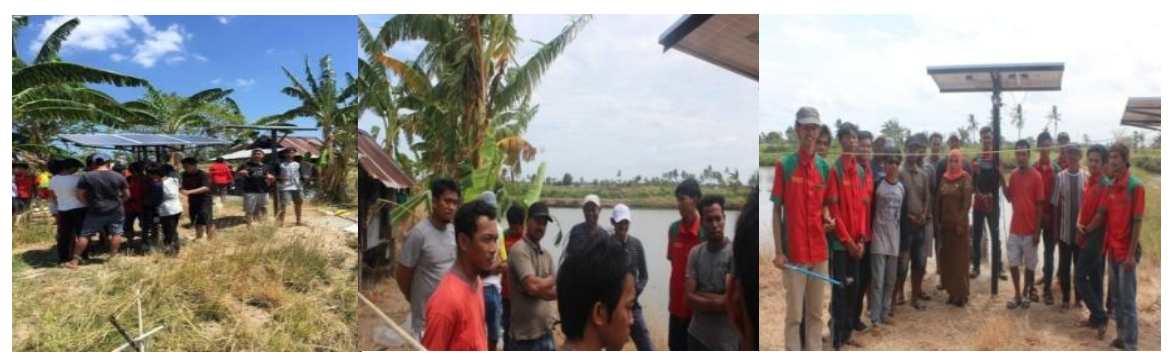

Gambar 5. Pelatihan Masyarakat tentang Pembuatan, Perakitan dan Pengoperasian Peralatan

Penerapan teknologi sel photovoltaik sebagai sumber energi untuk menjalankan pompa air dapat dilihat pada gambar 6. Pompa air yang digunakan dirakit dengan menggunakan motor DC 12 volt sebagai penggerak pompa. Motor tersebut dihubungkan ke modul sel PV sebagai penangkap sumber energi matahari. Pompa air ini merupakan prototipe yang telah diaplikasikan pada tambak udang. Penggunaan peralatan ini tentunya akan membantu penyediaan energi pada saat sumber energi matahari tersedia. Sebagian energi yang dihasilkan dari modul sel PV digunakan untuk mengisi baterai yang akan digunakan untuk penggunaan lainnya seperti sumber energi untuk radio, telepon genggam dan menyalakan lampu penerangan pada malam hari. Selain itu, pengembangan kapasitas pompa air untuk kebutuhan yang lebih besar dapat dilakukan dengan penggunaan motor berkapasitas lebih besar atau penambahan jumlah pompa air.

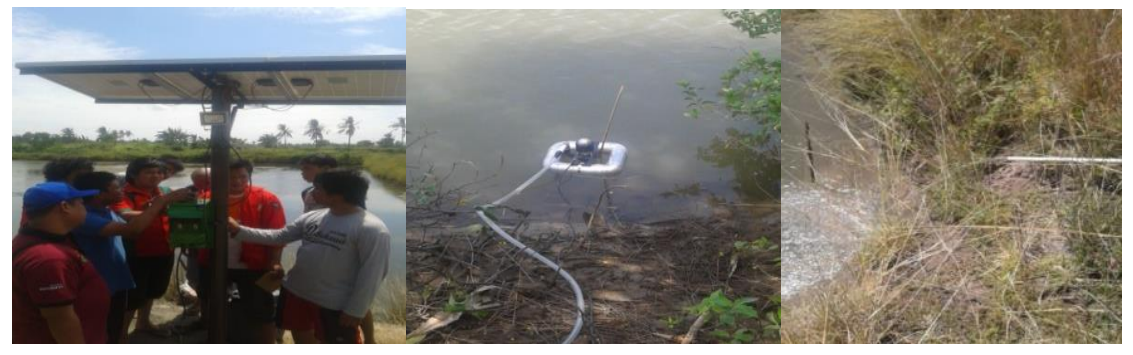

Gambar 6. Penerapan Teknologi Sel Photovoltaik sebagai Sumber Energi Pompa Air.

Kegiatan ini mendapatkan tanggapan yang sangat baik dari masyarakat karena memperkenalkan pemanfaatan sumber energi terbarukan, energi matahari. Penerapan teknologi sel photovoltaik sebagai sumber energi untuk menjalankan pompa air telah berhasil diaplikasikan. Dampak yang telah diperoleh dari kegiatan ini berupa: 1) ketertarikan masyarakat dalam mengaplikasikan teknologi ini; 2) pengetahuan dan keterampilan masyarakat petani tambak dalam penerapan teknologi pada pengelolaan tambak; 3) pembuatan areal tambak percontohan mandiri energi; 4) pembuatan lampu penerangan dengan teknologi sel PV di areal tambak sekitarnya telah dilakukan secara swadaya masyarakat; 5) pemerintah setempat juga telah menggunakan lampu penerangan teras kantor lurah dengan teknologi sel PV sebagai percontohan untuk masyarakat; 6) pengusulan pembuatan lampu jalan dengan teknologi sel PV pada beberapa jalan yang tidak terjangkau listrik PLN di daerah tersebut.

\subsection{Pengujian Lapangan terhadap Pompa Air sebagai Panduan dalam Aplikasi}

Pengujian lapangan terhadap pompa air dilakukan untuk membantu dalam implementasi pemanfaatan pompa air dengan penggunaan teknologi sel PV dan secara khusus untuk 
pemanfaatan pada tambak udang. Hasil pengujian ini berupa data operasional pompa air dan jumlah debit air yang dapat dipenuhi setiap harinya. Adapun skema instalasi pengujian lapangan dapat dilihat pada Gambar 7.

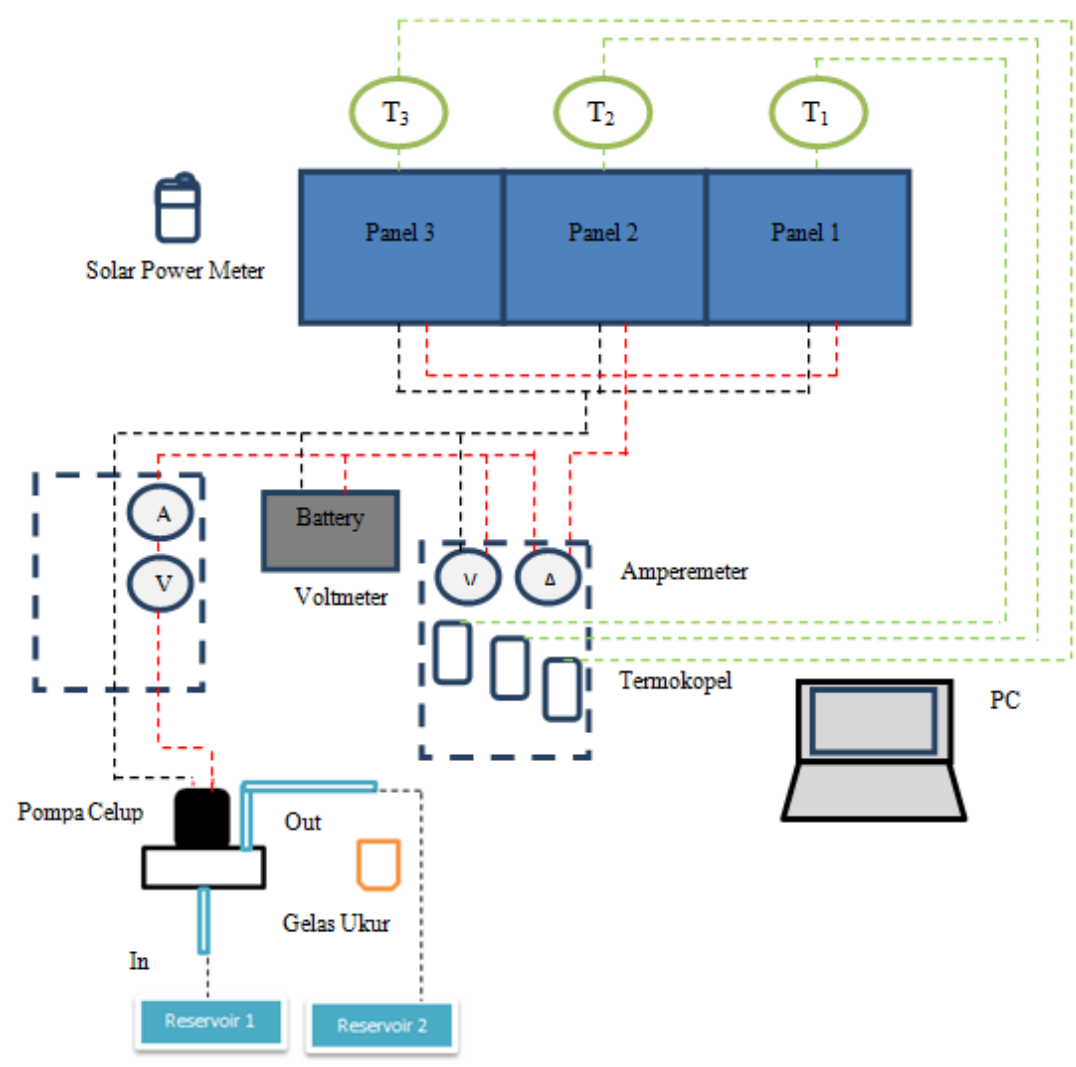

Gambar 7. Penerapan Teknologi Sel Photovoltaik sebagai Sumber Energi Pompa Air

Sistem pemompaan air dalam konsep mandiri energi di tambak udang berfungsi untuk mensuplai air penambah tambak yang berkurang karena penguapan dan faktor lainnya. Suplai energi listrik ke baterai berasal dari sel PV. Energi tersebut akan digunakan untuk menjalankan pompa air bila terjadi pengurangan air, penerangan pada malam hari dan penggunaan lain (radio, telpon genggam, dll). Untuk mengetahui performansi pompa air, pengujian lapangan dilakukan tanpa penggunaan baterai dan dengan penggunaan baterai.

\subsection{Pengujian Pompa Air tanpa Penggunaan Battery}

Pengujian dilakukan mulai dari pukul 08:00 sampai dengan 16:00 WITA (waktu lokal) dengan interval waktu pengambilan data adalah 5 menit. Pompa air yang digunakan adalah pompa air modifikasi dengan penggerak motor DC 12 volt. Daya yang disuplai ke pompa bervariasi berdasarkan intensitas matahari. Data yang diperoleh dari pengujian ini dapat dilihat pada grafik berikut: 


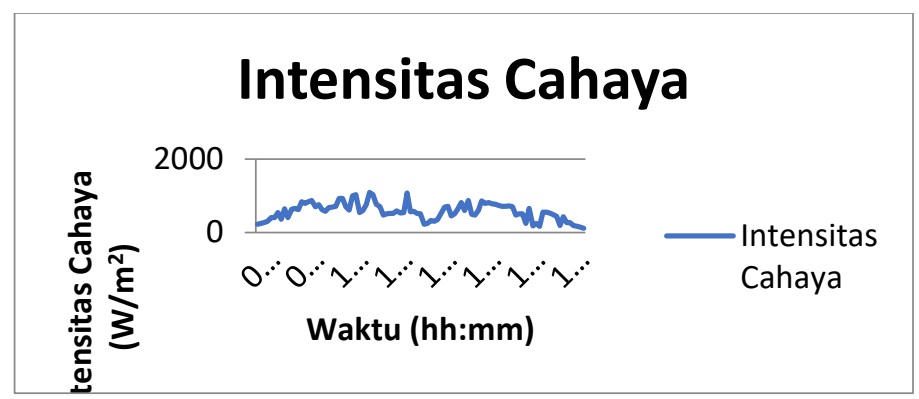

Gambar 8. Intensitas Matahari (Data: 2 Agustus 2016)

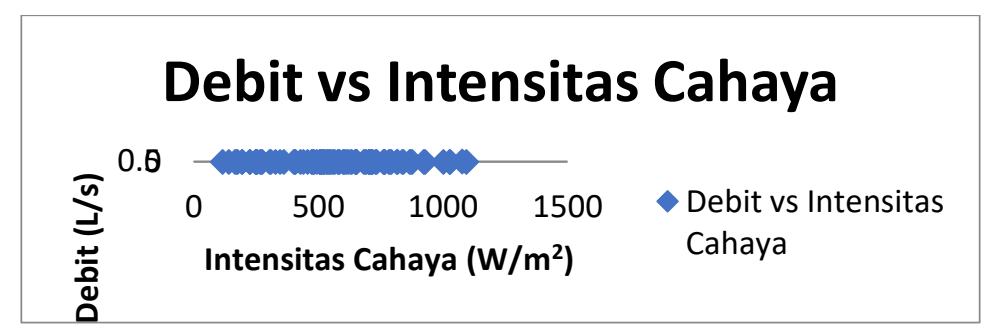

Gambar 9. Debit air terhadap Intensitas Matahari (Data: 2 Agustus 2016)

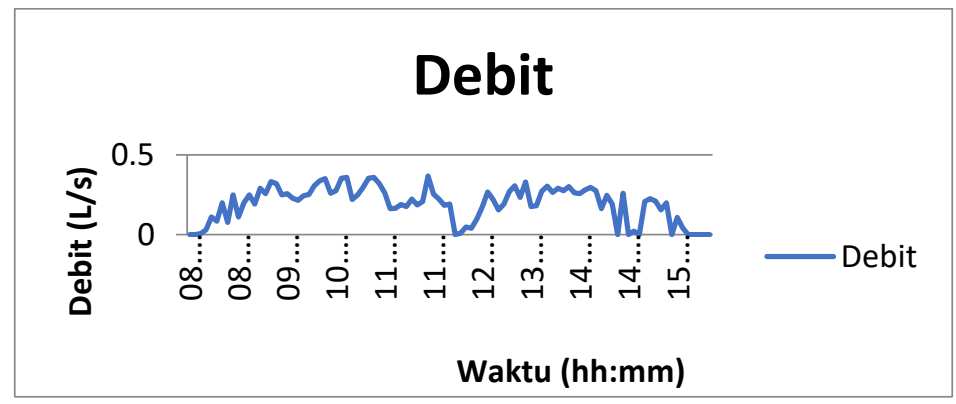

Gambar 10. Debit Air Harian Pompa Air (Data: 2 Agustus 2016)

Debit air yang dihasilkan oleh pompa dipengaruhi oleh intensitas matahari. Debit air maksimum yang bisa dicapai adalah sekitar $0.39 \mathrm{~L} / \mathrm{s}$. Adapun debit harian rata-rata dapat dilihat pada grafik 3. Debit rata-rata harian adalah sekitar $0.25 \mathrm{~L} / \mathrm{s}$. Dari data tersebut diatas dapat diketahui bahwa untuk memompa air sekitar $1 \mathrm{~m}^{3}$ diperlukan waktu sekitar 1.1 jam.

\subsection{Pengujian Pompa Air dengan Penggunaan Battery}

Pengujian dilakukan mulai dari pukul 08:00 sampai dengan 16:00 WITA (waktu lokal) dengan interval waktu pengambilan data adalah 5 menit. Pompa air yang digunakan adalah pompa air modifikasi dengan penggerak motor DC 12 volt. Daya yang disuplai ke pompa bervariasi berdasarkan intensitas matahari. Data yang diperoleh dari pengujian ini dapat dilihat pada grafik berikut: 


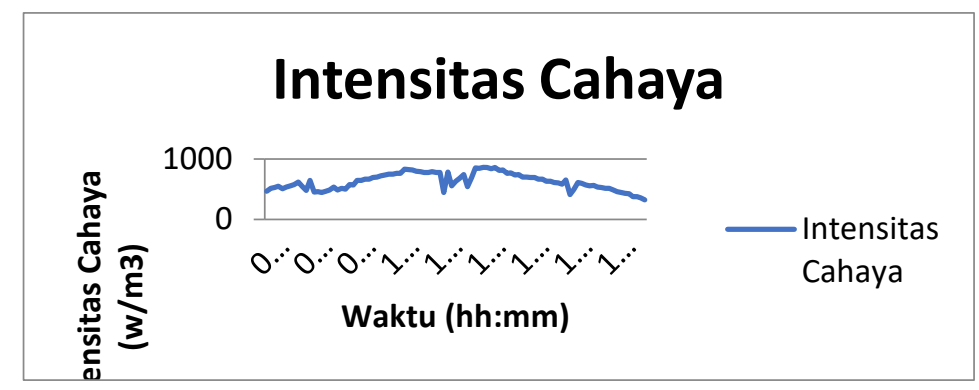

Gambar 11. Intensitas Matahari (Data: 8 Agustus 2016)

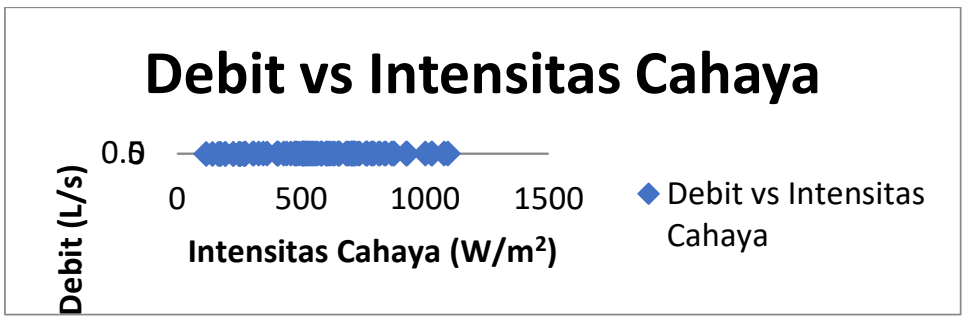

Gambar 12. Debit Air terhadap Intensitas Matahari (Data: 8 Agustus 2016)

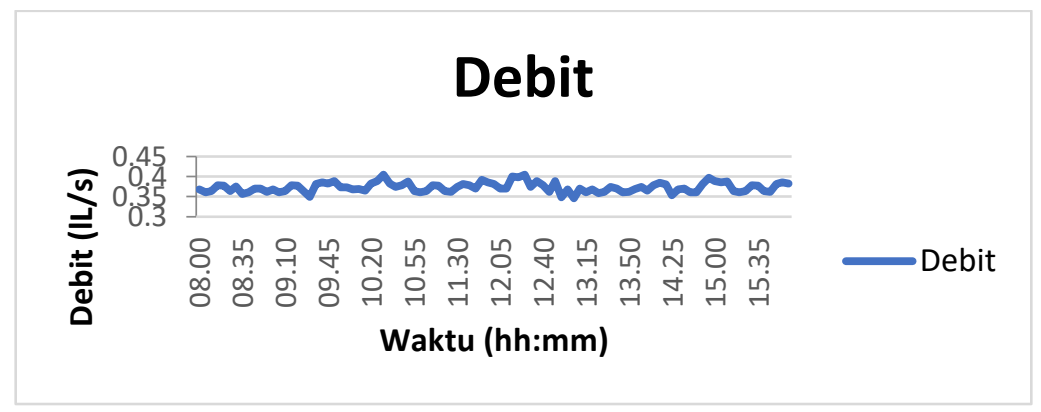

Gambar 13. Debit Air Harian Pompa Air (Data: 8 Agustus 2016)

Debit air yang dihasilkan oleh pompa dipengaruhi oleh intensitas matahari. Debit air maksimum yang bisa dicapai adalah sekitar $0.4 \mathrm{~L} / \mathrm{s}$. Adapun debit harian rata-rata dapat dilihat pada grafik 3 . Debit harian rata-rata adalah sekitar $0.375 \mathrm{~L} / \mathrm{s}$. Dari data tersebut diatas dapat diketahui bahwa untuk memompa air sekitar $1 \mathrm{~m}^{3}$ diperlukan waktu sekitar 0.7 jam.

\subsection{Contoh Pemanfaatan Pompa Air Sel PV}

Sebuah areal tambak memiliki panjang $50 \mathrm{~m}$ x $50 \mathrm{~m}$. Tambak tersebut memerlukan suplai air penambah setiap harinya karena proses evaporasi agar ketinggian air tetap stabil.

Laju evaporasi $\left(\mathrm{Q}_{\mathrm{ev}}\right)$ adalah: 


$$
\begin{aligned}
\mathrm{Q}_{\mathrm{ev}} & =\mathrm{Q}_{\mathrm{ev} \text { air tawar }} \times \mathrm{A}_{\text {tambak }} \\
& =0,37 \mathrm{~L} / \mathrm{s} / \mathrm{ha} \times \frac{1}{4} \text { ha } \\
& =0,0925 \mathrm{~L} / \mathrm{s} \\
& =333 \mathrm{~L} / \mathrm{jam}=0,33 \mathrm{~m}^{3} / \mathrm{jam}
\end{aligned}
$$

Sehingga tambak akan kehilangan air sebesar $0.33 \mathrm{~m}^{3}$ per jamnya. Kehilangan air dalam 1 (satu) hari (asumsi penguapan terjadi 8 jam sehari) diperoleh sebagai berikut:

$$
\begin{aligned}
Q_{\text {ev_harian }} & =0,33 \mathrm{~m}^{3} / \mathrm{jam} \times 8 \mathrm{jam} \\
& =2.64 \mathrm{~m}^{3} / \text { hari }
\end{aligned}
$$

Untuk mensuplai kekurangan air tersebut dengan pompa air sel PV dengan data debit yang telah diperoleh dari pompa ini yaitu sebasar $0.375 \mathrm{~L} / \mathrm{s}$ maka dibutuhkan waktu sekitar 2 jam. Hal ini menunjukkan bahwa untuk tambak dengan luas 50 x 50 meter dan kebutuhan suplai air sebesar $2.64 \mathrm{~m}^{3}$ maka pompa akan dijalankan selama 2 jam per hari.

\section{Kesimpulan}

Pengembangan sumber energi terbarukan pada tambak udang di kabupaten Pinrang Sulawesi Selatan telah dilaksanakan melalui Konsep Mandiri Energi dengan penerapan teknologi sel photovoltaik. Teknologi ini menyediakan sumber energi listrik untuk menjalankan pompa air dan penggunaan lainnya di areal tambak udang. Peningkatan pengetahuan dan keterampilan masyarakat dalam upaya pemberdayaan masyarakat dalam pemanfaatan energi terbarukan dengan penerapan teknologi sel photovoltaik tersebut dilakukan melalui kegiatan sosialisasi dan implementasi termasuk pelatihan. Penyediaan sumber energi alternatif untuk menjalankan peralatan pendukung pada tambak udang seperti pompa air dan penggunaan lainnya telah tersedia. Beberapa kelompok masyarakat telah dilatih dalam pembuatan dan pengoperasian peralatan tersebut diatas. Pengetahuan dan keterampilan yang telah dimiliki tersebut diharapkan dapat dikembangkan secara mandiri oleh masyarakat. Pemerintah setempat dapat menyusun program pemberdayaan kelompok masyarakat tersebut secara lebih sistematis untuk kemajuan daerah tersebut. Kegiatan ini diharapkan dapat terus ditingkatkan dalam berbagai program kemitraan pendampingan yang lebih luas dengan melibatkan institusi terkait. Pengujian lapangan terhadap pompa air juga telah dilakukan sebagai panduan dalam aplikasi. Debit air rata-rata harian dari pompa air adalah sekitar $0.375 \mathrm{~L} / \mathrm{s}$. Sebagai contoh, tambak udang seluas 50 x 50 meter mempunyai kebutuhan suplai air sebesar $2.64 \mathrm{~m}^{3}$ maka pompa akan dijalankan selama 2 jam perhari.

\section{Ucapan Terima Kasih}

Ucapan terima kasih disampaikan kepada LP2M UNHAS atas kerjasamanya dan KEMENRISTEKDIKTI atas dukungan dananya dalam pelaksanaan kegiatan pengabdian masyarakat ini.

\section{Daftar Pustaka}

Azhar, F., Nasri, M.Z. (2015). Analisis Unjuk Kerja Sistem Prototipe Kincir Aerator Tambak Udang Tenaga Matahari, [Skripsi]. Program Sarjana Universitas Hasanuddin.

Arfandy, R., Arif, E., Jalaluddin. (2016). Pemanfaatan Energi Matahari Sebagai Penggerak Pompa Rumahan, Prosiding Seminar Nasional ke 3 Rekayasa Material, Sistem Manufaktur dan Energi, 16 - 17 November 2016. 
Dinas Kelautan dan Perikanan. (2012). http://dinaskelautanperikanan.blogspot.com/2012/04/kondisi-dan-potensi-budidaya-udangdi.html.

Hasbi, H.S. (2014). Analisis Peningkatan Efisiensi Sel Surya dengan Aliran Air Pendingin di bawah Panel, [Tesis]. Pascasarjana Universitas Hasanuddin.

Jalaluddin, Jalil, A.R., Tarakka, R., Wardi. (2015). Pemberdayaan Masyarakat dengan Pemanfaatan Sumber Energi Terbarukan pada Tambak Udang, Agrokreatif, Jurnal Ilmiah Pengabdian kepada Masyarakat, November 2015, Vol 1 (2): 136-141, ISSN 2460-8572, EISSN 2461-095X.

Jalaluddin, Mire, B. (2015). Performance Investigation of Photovoltaic Module with Solar Tracking, Proceeding of the $2^{\text {nd }}$ International Symposium on Smart Material and Mechatronics. Makassar-Gowa, 26-29, October, 2015, ISSN: 978-979-17225-8-2.

Jalaluddin, Himran, S., Arief, S., Khalik, A. (2016). Studi Eksperimental Performansi Modul Photovoltaik dengan Pendinginan Air, Proceeding Seminar Nasional Tahunan Teknik Mesin XV (SNTTM XV) Bandung 5 - 7 Oktober 2016.

Mahmud, U., Sumantadinata, K., Pandjaitan, N. H. (2007). Pengkajian Usaha Tambak Udang Windu Tradisional di Kabupaten Pinrang, Sulawesi Selatan, Jurnal MPI 2(1): 70-85.

Shiddiq, A., Multazam. (2015). Pemanfaatan Energi Matahari Sebagai Penggerak Pompa Tambak, [skripsi]. Program Sarjana Universitas Hasanuddin. 